\title{
Dual Identity in Interethnic Context
}

\author{
KOME - An International Journal of Pure \\ Communication Inquiry \\ Volume 2 Issue 1 p. 28-36 \\ (C) The Author(s) 2014 \\ Reprints and Permission: \\ kome@komejournal.com \\ Published by the Hungarian Communication
}

Studies Assoiciation

\author{
Barbara Sólyom \\ Corvinus University of Budapest, Doctoral School of Social Communication, Hungary
}

\begin{abstract}
The field of social psychology, over the past few years, has created a new term to describe threats to collective identity called social identity threat. This study sets out to present how social identity threat may arise between different ethnic groups, describes its conditions and determining factors, possible responses and forms of reaction to such dangers; furthermore, it also covers factors which decide what self-defense strategy one may choose. Finally, the possible outcomes and consequences are examined. The article discusses the phenomenon of social identity threat using empirics of theoretical and international research applied to the coexistence of ethnic Germans and Hungarians in a village in Hungary. Exploring the life of the settlement is part of a broader empirical research.
\end{abstract}

Keywords: ethnic minorities, interethnic relationships, group identity, stereotypes, prejudice, social identity threat

\section{Introduction}

In order to accurately describe the notion of social identity threat, one must first define the term of collective identity and its evolution and importance has to be briefly summarized as well. Aspects nurtured by emotions and knowledge applied or related to our group forms an essential part of ourselves as, according to the social identity theory, one's identity originates from one's personal group. These associations determine in what ways we differ from or are similar to other members. This means that our personal identity includes the mentality, worldview and value system of our group and since we are members, our own identity simultaneously influences and determines norms and beliefs within the group. Personal and collective identities thus mutually determine each other and this relationship is apparent in the case of stereotypes and prejudice as well; personal preconceptions and generalizations affect those of the group and vice versa. 
Collective identity, that is the feeling of belonging to a group, is defined by two factors and from two directions: one is that we define ourselves as group members and the second is that other persons perceive us as belonging to a certain group.

Numerous studies in the field of psychology, sociology and social psychology confirm that the significance of collective identity stems from the fact that we constantly evaluate our group higher and place it above other groups based on aspects important to us. Collective identity is essential for a member as it is the primary source of one's self-esteem. (Turner \& Oakes 1986).

\section{Threats to nationality and ethnic identity}

Nationality and ethnic identity are part of social identity. They mainly serve to help individuals place themselves between various ethnic groups by using the dimensions of familiar and foreign. In case of the ethnic German community presented in the article, we may define ethnic identity as follows (Bindorffer - Sólyom 2007): feeling of attachment and self-identification of an individual to a group to which that person was born into, and where said individual acquires a set of knowledge related to ethnicity which will be the basis of comparison later on. In this knowledge system we find the common awareness of origin, the cultural repertoire, traditions and values determining the similarity of habit, religion and the practice of constructing and operating certain survival strategies; in other words, all that ensures identification and separation.

Identity threat is related to the phenomenon called stereotype threat (Steele and Aronson 1995). Steele and Aronson (1995) were the first to perform experiments demonstrating that stereotype threat can undermine intellectual performance in academic context. The results showed that performance was poorer only among those African-Americans whose racial identity was made salient prior to testing. These studies established the existence of stereotype threat and provided evidence that stereotypes suggesting poor performance, when made noticeable in a context involving the stereotypical ability, can disrupt performance, may produce doubt about one's abilities, and cause an individual to dissociate from one's ethnic group. This effect was termed stereotype threat. More than 300 published papers show the effects of stereotype threat on performance in a variety of domains.

Social identity threat (Vorauer 2003; Síklaki 2010; Daróczi 2011) may be defined as a hazard to collective identity. We are worried that others may judge us based on stereotypes applied to the group we belong to or that our behavior reinforces these stereotypes. This basically stems from meta-stereotypes: what stereotypes are used regarding the group according to its own individual member. These meta-stereotypes may be the source of social identity threat. They are particularly visible in case of interactions between minorities, notably ethnic groups. For example, the characteristics of unreliability, athleticism, exceptional aggressiveness, laziness are among meta-stereotypes of African-Americans meaning this is what they expect other Americans will see them as in case of interaction.

Threats to identity may appear as a result of various factors. These may include a visible difference in appearance or being easily able to classify one as member of a certain group. In such situations, an individual may "rightfully" consider the possibility that other persons belonging to different groups will define and evaluate him/her based on stereotypes and as someone who is member of a particular group. Aside from appearance, threats to identity may also be related to differences in social status.

Meta-stereotypes originating from interactions between minority ethnic groups do not necessarily cause social identity threat. The level of sense of fear is determined by how and to 
what extent group members perceive stereotypes being applied against them. At this point, the role of attitudes should also be mentioned (Vorauer-Kumhyr 2001): less prejudiced individuals will feel less threatened by meta-stereotypes compared to those with serious preconceptions since the former believe that members of other groups will not apply these stereotypes against them. Another important factor is whether a fellow group member or someone belonging to another group is present in the given situation and what is his/her behavior (Vorauer 2003). In an experiment, persons with less prepossessions thought that if a member of another group is present and is surrounded by his peers, that group member will have a much more negative view towards the individual, compared to a scenario in which $\mathrm{s} / \mathrm{he}$ were evaluating the situation alone. However, if we consider the opinion of an individual with many prejudices, a member of an external group will see the person less negatively if his/her peers are present as compared to an evaluation when s/he is alone. This means that the combination of individual attitudes and a social context determines how members of another group view the members of the in-group, and to what extent various ethnic groups experience social identity threat during interaction.

Let us look at the phenomenon of social identity threat using the relationship between the Hungarian majority and the German minority. In a study conducted in an ethnic German village of Pest county, Györgyi Bindorffer (Bindorffer 2001) considered the issue of interethnic relations as well. In a research of my own (Sólyom 2004), I also found features of majority-minority relations and manifestations at an intergroup level. I observed that the ethnic German population examined has a dual identity. They feel, live and define themselves both ethnic German and Hungarian simultaneously. Over the decades, they managed to acquire the most essential, most necessary knowledge in order to live securely, without any threats, and to participate in communication with the Hungarian majority as a survival strategy. Ethnic Germans adopted elements which are acceptable, useful and easy to integrate and which comply with a certain set of requirements; they are willing to acquire only as much as a dual identity, and are opposed to full homogeneity, assimilation and surrender. Members of the ethnic German community also develop, define and apply their own negative stereotypes towards the majority and have their prejudices operative. Nevertheless, reactions given to social identity threat do not necessarily follow the group pattern in every situation and in case of all members. Possible responses include full assimilation, detachment from the minority group, surrender, or departure from the group. Compromise as a solution also means dual identity. Dual identity thus is a certain response to factors, phenomena, tendencies that may threaten ethnic German identity and helps not only with self-preservation but also reduces inter-group conflicts. Such a duality means that when ethnic Germans identify themselves as Hungarians, negative stereotypes and attitudes towards Hungarians become less condemnatory, less of an insult and less exclusive and social identity threat becomes less significant. Experience gained from inter-ethnic relations and conclusions arrived at, emotional influences as well as assimilation affect and determine relations of the two ethnic groups in an opposite direction.

\section{Responses to social identity threats}

Ethnic groups respond to social identity threat in multiple ways, and interaction between different groups may also take several forms (Síklaki 2010). One possibility is avoiding any contact between different groups, or escaping from these. This means - physically, mentally - we prefer not to interact with another group in order to protect our self-esteem. For instance, before the Second World War, the local elite in the ethnic German settlement (wealthy peasants and intellectuals) avoided interactions with local stone miners. They lived, spent their free time in different parts of the village, they frequented other people and they 
did not allow their children to marry with those outside their group. They were proud of their social status and did everything in order to keep their positions and wealth. Another possible way to defend our self-esteem and positive image of ourselves is rejecting the views of other group(s). This of course is the case if our self-esteem is threatened - for example, when we receive negative feedback on our level of intellect -, we have an increased need for such a mechanism and prejudice becomes even stronger towards group members to which we apply stereotypes. This is due to the fact that we tend to evaluate people to whom we apply stereotypes more negatively and criticize them more profoundly. If our self-esteem is endangered, this process is further reinforced. If we have a chance to denigrate a member of the group to which we have attached stereotypes, we may significantly improve our selfesteem. Thus prejudice in this case has a reinforcing, an empowering effect. Such forms of defense have been used in ethnic German-Hungarian interactions, when the minority felt that stereotypes attached to them may be negative, e.g. ethnic German penny pinching, the importance attached to perceptions and superficialities.

Another possible form of "self-defense" may be to simply ignore the threat, not to fight it and to attempt to strengthen another aspect of our personality, thus highlighting and supporting our generally positive view of ourselves. This process may also be of prejudiced nature. However, if our self-esteem is not damaged, is not threatened or something previously has improved it, we do not need the aid of stereotypes and we do not reject other groups (SmithMackie 2001).

A third solution to avoid social identity threat is coordinating behavior during social interaction. People belonging to the majority or an ethnic minority may also respond to threats against their identity by modifying their behavior in order to ensure a good impression in the eyes of their partners. This means they change their behavior in order to avoid confirming an already existing stereotype and they harmonize it with stereotype expectations applied to the group they belong to. The ethic German community is again an adequate example against whom a stereotype is that they work really hard, they save a lot, their first and foremost objective is increasing wealth and thus they are incapable of enjoying life due to the lot of work, the ascetic attitude and puritan lifestyle. They indeed live like this but they are proud of their mentality. They never deny these features, they never try to give an explanation, and instead they accept and are proud of these thereby reinforcing their selfesteem, identity while they also adhere to an external group's precognition about them.

„Everybody, always, in all ways possible, had to increase wealth. This was an obligation, even if it meant sacrificing individual happiness. As they said: wealth marries wealth" - said one of my interviewees, a native ethnic German woman in her nineties when we were discussing what influenced the possibility of ethnic German-Hungarian mixed marriages.

The question 'who opts for which strategy' in order to avoid any dangers to his/her identity is determined by motivation, the efficiency of the self, power and status. Those who are motivated to ensure a better image and believe in success also believe that they have the capacities necessary to choose the strategy of controlling behavior. This behavior is thus a common feature of wealthy ethnic German families. However, those who lack determination and/or do not believe that they are capable of successfully influencing others' perception of themselves, will instead rely on the other two strategies, namely avoidance or rejecting the external group's views. Attitudes related to a given situation are also important. If tolerance dominates, people tend to strive for harmony, harmonic interactions and not rejecting opinions of other groups or criticizing these latter. Nevertheless, if they counter hostile attitude, they will become similar and fight takes place. If we examine selection of strategy from the viewpoints of status and power, we may conclude that persons of higher status are able to behave in a riskier way, choosing from a wider range of strategies which are of greater effects, compared to individuals who have a lower status. They express their feelings and 
opinions more efficiently, they are more apt and their behavior during social interactions is much more diverse. They are more self-reliant, decisive, confident and tend to be "voices of groups" when compared to people of a lower status (Fiske 1993; Fiske 2006). During my research conducted in the ethnic German community, I have concluded that different strategies of defending one's identity - in order to attain the goal - may also be mixed with each other. If relations of the ethnic Germans and Hungarians in the village are considered, we may see the following results (Bindorffer 2001; Sólyom 2004). Throughout history, ethnic Germans have repeatedly been assimilated by force; their positive ethnic features were looked down on. They were demanded to transpose values of the Hungarian majority as quick as possible while Hungarians did not take up any ethnic German mentality such as work culture of peasants, way of life, value system and way of thinking even after a considerable period of time. Ethnic Germans did everything to strengthen their identity and at the same time could not successfully oppose assimilation. Prior to the Second World War, the community of the village was rather closed which defined relations and communication in and between subgroups. A rigorous adherence to rules was typical: they established how one may and should behave with others, whom an individual may talk to, whom they can marry, or kids may or may not play with. They had a hard time accepting the arrival of outsiders. However, rules started to become more flexible over time due to certain historical and social events (e.g. the Second World War, the 1947 relocation, obligatory school and commute to work) following which the village became more open, acceptant but one can still sense that indigenous families allow outsiders to approach them only to a certain point.

Ethnic Germans classified themselves into different categories, groups. The scale ranged from acceptance to full rejection: majority Catholic Hungarians; local, native Hungarians of protestant faith who form a minority; Hungarians from neighboring Slovakia or the "settlers" (who arrived as a result of the exchange of population); people from nearby villages and communities (most of whom occupied empty houses of ethnic Germans after 1947). Ethnic Germans' hostility was strongest (category of full rejection) towards Hungarians who moved into houses of ethnic German families who were relocated or forced to share houses with other minority families after their wealth has been taken away. The labels 'Protestant' and 'settler' became part of the category to be rejected reaching the same level as that before the Second World War, an ethnic German was not allowed to marry a settler and if so, he/she would have been shamed, looked down on, excommunicated and the relationship would have been ruined. Children of ethnic Germans could not play together with settlers' kids, any form of contact was prohibited and the ethnic German community avoided any kind of interaction and maintenance of communication. Hungarians of Slovakian origin were regarded as a source of all problems, ethnic Germans transferred their scapegoat role onto them. The former were considered foreigners who took over their wealth, the dangerous, fear-inducing, and oppressive power to which only strongly negative content had been attached. Shared daily life, forcedly living together, having the same workplace, school, commute and Catholic religion softened tensions but older people continue to hold a grudge and to them the term "settler" still has negative connotations. These are thus not ethnic categories, but "simply" negative value judgments, prejudices. The local ethnic German community categorized Hungarian villagers based on denomination which was thus the ground for labeling. Protestant Hungarians, a minority in the village, were one group while Catholic Hungarians from outside the settlement were considered different. Catholic Hungarians were of the same faith as ethnic Germans so they were accepted more easily than Protestants, which was apparent in case of mixed marriages as well; they were more likely to approve of a marriage with a Hungarian Catholic. They were also unfriendly towards Hungarians of nearby settlements, people whom they considered lazy, messy, whom they looked down on but they did not fear. The German community never allowed Roma to settle in the village, anyone 
who still stayed managed to do so as a result of a mixed marriage but only very few people. The ethnic German minority thus identified and kept trace of its enemies. Acceptance has slowly increased over time and the village is now more open, tolerant but still establishes categories. On the hill above the village, those who live in the area of vacation houses are foreigners to whom the outsider label has been attached, while permanent residents of the village who resettled here have been classified according to their behavior and attitude. Those who wanted to integrate have to take steps in order to be accepted e.g. have to attend Catholic church, have to send their children to the local kindergarten and school, should attend ethnic German balls and concerts, and if can play an instrument should participate in one of the local bands. Mixed marriages are becoming more and more common but non-ethnic German parties, although considered less of an outsider, will still never enjoy the same status.

The bond of marriage may present one of the greatest dangers to minority identity thus it is not surprising that this is where social identity threat is most apparent possibly even on the form of rejection:

"It was an ethnic German-Hungarian issue because Hungarians were unable to get used to the situation, they wanted to be involved in everything, parents did not allow certain relationships and prohibited them, but the young allowed themselves to be convinced" - said one of the interviewees, a local ethnic German man in his 80s.

„Family wanted to have a say in everything, the woman escaped, the relationship was ruined and the outsiders was picked on" - said a 60-some woman who moved into the village later.

„It was a Hungarian-German marriage, at first condemned, especially by those who considered themselves fully German, but it was later acknowledged. The situation further improved later on, the war loosened up many such rules, moral principles, forms of behavior, people mixed to a considerable extent, many have been in Russia and as mobility increased, so did life changed and many have seen a lot of things that were unheard of in the village, so ancient 'remnants' dissolved considerably later on" - said a man in his 80s who had also resettled in the village.

The question of identity is also raised within the ethnic German minority. Religion is a fundamental factor among local and non-local members of the German community. To be an ethnic German does not mean a common conscience, identification for all members in Hungary. Catholics belong to the "we" group while Lutherans are "them". Aside from religion, different levels of assimilation, geographical fragmentation and different native language or dialect are also reasons why ethnic Germans do not constitute one single community. However, this is also changing as groups are getting gradually approaching each other.

„In the old times, there was a strong discrimination; a Protestant wanting to marry a Catholic had always caused huge problems. If they had already got married, it was accepted as it was a fact, unchangeable, people had to put up with it... This conflict has generally disappeared but to a slight extent may still be present on a personal level in case of certain individuals. Nowadays, it has again become important, but also due to the character of the two religions. A Protestant is a stubborn Calvinist, a persistent Calvinist" - says an 80 year old ethnic German interviewee who is a native to the village. 
The relationship between ethnic Germans and other Germans outside Hungary is another identity-dimension. Ties of the local minority and Germans is becoming stronger as locals have direct experience with Germans living in Germany based partially on media as well as relatives, friends and personal experience. Following the repatriation in 1947, many relatives, friends who did not come back, those who returned and more and more intense relations between sister cities also fuel positive stereotypes of local ethnic Germans regarding other Germans, and they even want to become like them in certain fields of life. The multifocal relationship results in a considerable effort to teach and practice German to the extent that there is a German kindergarten and elementary school in the village, that is children learn and practice the language from a quite young age and they learn a German that is different from the one spoken in their homes, that differs from the dialect of the elders. Nevertheless, separation, emphasizing differences is still present: this is based on language, citizenship, patriotism and the bad, economy-oriented mentality of Germans according to the local minority. Given all these, the ethnic German minority is still situated closer to Hungarians than Germans of their home country, due to dual identity, everyday knowledge, living together and sharing a language.

\section{Responses to social identity threat may have similar outcomes}

Avoiding interaction is the most harmful strategy when it comes to fighting stereotypes - this approach means no actual experience will be gained regarding the other group -shameing another group and rejecting its views will result in retaliation and there will never be understanding and acceptance between the two opposing sides. Chances of reducing prejudices may considerably vary. Evading a strongly judgmental person means the minority group protects itself from negative stereotypes. However, if one interacts with said person, we may experience a serious damage to our values. Meanwhile, avoiding a person with less precognitions means there is no actual chance to decrease those and is not an efficient strategy. Getting to know that person and revealing ourselves and group would be worth in this case, as Allport writes in his classic work (Allport 1977). The relationship between ethnic Germans of the selected village and other national minorities is also interesting. Regarding the opinions of the Hungarian majority on minorities of the country, Germans enjoy the top spot. They are viewed as Hungarians as they have assimilated to a sufficient extent in the eyes of the majority; they are equally developed and have a similar way of thought. Ethnic Germans and Hungarians resemble each other the most, Hungarians accept them individually and collectively as well, and view them positively. Negative stereotypes of ethnic Germans are also much weaker towards Hungarians compared to against other nationalities. The level of assimilation is directly proportionate to mutual acceptance. During the period when the village formed a closed community, Hungarians had been called pessimists, people strive on failure, they prefer having fun and spending time in the pub, irresponsibly spending their wealth, and they are not hardworking, diligent and lacking in prudence. These labels have since become positive, Hungarians have acquired a mentality similar to ethnic Germans over the last 20-30 years and the two communities accept each other. This enforces self-esteem in both groups as well as relations. 


\section{Summary}

According to the theory of social identity, individual identity is defined by the mindset, value system and character of one's group and our own personal identity affects norms and behavior of our group. This mutual impact shapes prejudices and stereotypes as well. The fact that we continuously rank our own group higher compared to other groups according to standards more important to us shows the importance of collective identity. Social identity is also essential for the group member as a considerable part of his/her own self-esteem originates from the group the person belongs to.

Dangers to collective identity are called social identity threat. These stem from metastereotypes: we are afraid that we will be judged by others based on stereotypes applied to the group we belong to or we fear that our personal behavior will reinforce such a stereotype. These meta-stereotypes are particularly relevant in case of interactions between different minorities, most notably ethnic groups.

Hazards to identity may arise due to a number of factors, including physical appearance or differences in social status.

How threatened one feels is influenced by how and to what extent group members consider stereotypes applied to them as valid, what attitude they have, whether other member(s) of the in-group or other groups are present in the particular situation and how they behave.

Ethnic groups may respond to social identity threat in a number of ways: they may avoid interaction of groups; they can reject another group's views; and they may coordinate behavior. Who opts for which strategy in order to avoid a threat to his/her identity depends on motivation, the efficiency of the self, power and social status.

I considered the case of an ethnic German village located in Pest County to examine the phenomenon of social identity threat. Based on my experience, the minority German population has a dual identity: they feel and consider themselves ethnic Germans and Hungarians simultaneously. As a survival strategy, they have acquired the most essential, most necessary knowledge in order to participate in coexistence with the Hungarian majority. An ethnic German adopts elements which are useful, easily attainable and acceptable and which satisfy certain basic requirements but will only be willing to have a dual identity, rejecting full assimilation and surrender of oneself. Furthermore, ethnic Germans also maintain certain negative stereotypes and prejudices towards the majority. Dual identity is thus a form of response to elements, phenomena and tendencies potentially dangerous to ethnic German identity and it also helps reducing conflicts between different groups, while helping self-preservation.

\section{References}

Allport, Gordon W. 1977. Az elöitélet [The prejudice]. Budapest: Gondolat, 369-394.

Bindorffer, Györgyi, 2001. Kettős identitás [Dual identity]. Budapest: Új Mandátum-MTA Kisebbségkutató Intézet.

Bindorffer, Györgyi - Sólyom, Barbara, 2007. A pomázi szerbek identitása [The identity of Serbs of Pomáz]. In: Bindorffer Györgyi (ed.): Változatok a kettös identitásra [Variations of the double identity]. Budapest: Gondolat - MTA Etnikai-Nemzeti-Kisebbségkutató Intézet, 188-236.

Daróczi, Ágnes (ed.), 2001. Cigányság-identitás-kultúra-történelem [Roma-identity-culture-history]. Budapest: Magyar Müvelődési Intézet és Képzőművészeti Lektorátus. 
Fiske, Susan T. , 1993. Controlling other people: The effect of power on stereotyping. American Psychologist 48, 621-628.

Fiske, Susan T. 2006. Társas alapmotívumok [Basic core motives]. Budapest: Osiris, 511-582.

Síklaki, István, 2010. Elöitélet és tolerancia [Prejudice and tolerance]. Budapest: Akadémia, 160-178.

Smith, Eliot R. - Mackie, Diane M. 2001. Szociálpszichológia [Social Psychology]. Budapest: Osiris, 208-248.

Sólyom, Barbara, 2004. Társadalmi és házassági mobilitás Dunabogdányban [Social and marriage mobility in Dunadogdány]. Tabula, 7.(I), 71-96.

Steele, Claude M. - Aronson, Joshua, 1995. Stereotype threat and the intellectual test performance of African Americans. Journal of Personality and Social Psychology 69(5): 797-811.

Turner, John - Oakes, Penny, 1986. The significance of the social identity concept for social psychology with reference to individualism, interactionism and social influence. British Journal of Social Psychology 25(3): 237252.

Vorauer, Jackie D. - Kumhyr, S. 2001. Is this about you or me? Self - versus other-directed judgments and feeling in response to intergroup interaction. Personality and Social Psychology Bulletin 27, 706-719.

Vorauer, Jackie D. 2003. Dominant group members in intergroup interaction: Safety or vulnerability in numbers? Personality and Social Psychology Bulletin 29, 498-511. 